\title{
ANALISIS FAKTOR RISIKO LINGKUNGAN YANG BERHUBUNGAN DENGAN RIWAYAT MALARIA
}

\author{
Rizka Sofia ${ }^{1}$ \\ ${ }^{1}$ Bagian Parasitologi Fakultas Kedokteran Universitas Malikussaleh \\ Lhokseumawe 24311, Indonesia \\ Corresponding author : drrizkasofia@gmail.com
}

\begin{abstract}
Abstrak
Malaria merupakan penyakit infeksi menular yang masih menjadi salah satu masalah kesehatan utama di dunia karena sering menimbulkan kejadian luar biasa, berdampak luas terhadap kualitas hidup dan ekonomi, serta dapat mengakibatkan kematian. Penyakit malaria sangat dipengaruhi oleh faktor-faktor lingkungan, perubahan signifikan dari salah satu atau beberapa faktor lingkungan. Oleh karena itu, keberhasilan pengendalian malaria tidak dapat tercapai tanpa mempertimbangkan faktor-faktor tersebut. Penelitian ini bertujuan untuk mengetahui faktor risiko lingkungan yang berhubungan dengan riwayat malaria. Penelitian ini dilakukan pada siswa SMA Negeri 1 Krueng Sabee, Aceh Jaya. Jumlah sampel dalam penelitian ini sebanyak 94 responden. Metode analisis data yang digunakan adalah analisis univariat, analisis bivariat menggunakan Uji Chi Square dan analisis multivariat menggunakan regresi logistik. Hasil penelitian menunjukkan bahwa lingkungan responden sebagian besar dalam kategori buruk $(66 \%)$. Hasil análisis bivariat menunjukkan bahwa faktor risiko keberadaan kawat kasa pada ventilasi, faktor risiko kondisi dinding rumah, faktor risiko keberadaan langit-langit, dan faktor risiko keberadaan semak-semak di sekitar rumah mempunyahi hubungan yang signifikan dengan riwayat malaria pada siswa SMA Negeri 1 Krueng Sabee. Hasil analisis multivariate menunjukkan bahwa faktor risiko keberadaan semak-semak di sekitar rumah sangat berpengaruh dengan riwayat malaria para siswa SMA negeri 1 Krueng Sabee (nilai p sebesar 0,030 dan nilai OR sebesar 18,716).
\end{abstract}

Kata kunci: Faktor Risiko Lingkungan;Riwayat Malaria 


\title{
ANALYSIS OF ENVIRONMENTAL RISK FACTORS RELATED TO THE HISTORY OF MALARIA
}

\begin{abstract}
Malaria is an infectious disease that remains one of the major health problems in the world as they often give rise to extraordinary events, the greatest impact on quality of life and economy, and may result in death. Malaria is strongly influenced by environmental factors, a significant change of one or more environmental factors. Therefore, the success of malaria control can not be achieved without considering these factors. This study aims to determine the environmental risk factors associated with a history of malaria. This research was conducted at SMA Negeri 1 Krueng Sabee, Aceh Jaya. The number of samples in this study are 94 respondents. Data analysis methods used univariate analysis, bivariate analysis using Chi Square and multivariate analysis using logistic regression. The results showed that most of the respondents neighborhood in the bad category (66\%). The results of bivariate analysis showed that risk factors for the presence of wire netting on the ventilation, a risk factor for the condition of the house walls, a risk factor for the presence of the ceiling, and risk factors for the presence of bushes around the house have significantly associated with a history of malaria in students of SMA Negeri 1 Krueng Sabee. The Results of multivariate analysis showed that risk factors for the presence of bushes around the house is very influential with a history of malaria in students of SMA Negeri 1 Krueng Sabee ( $p$ value of 0.030 and $O R$ value of 18.716).
\end{abstract}

Key words:Environmental risk factor, Malaria History 


\section{Pendahuluan}

Malaria merupakan penyakit infeksi menular yang masih menjadi salah satu masalah kesehatan utama di dunia karena sering menimbulkan kejadian luar biasa (KLB), berdampak luas terhadap kualitas hidup dan ekonomi, serta dapat mengakibatkan kematian. Penyakit malaria dapat bersifat akut, laten atau kronis. Malaria disebabkan oleh parasit Plasmodium yang hidup dan berkembang biak dalam sel darah merah manusia yang ditularkan oleh nyamuk malaria (Anopheles) betina. Malaria dapat menyerang semua orang baik laki-laki ataupun perempuan dan pada semua golongan umur. ${ }^{1}$ Oleh karena itu, malaria merupakan salah satu penyakit yang menjadi sasaran prioritas komitmen global dalam Milleniun Development Goals (MDGs) yang dideklarasikan oleh 189 negara anggota PBB pada tahun 2000. World Health Assembly (WHA) pada tahun 2005 menargetkan penurunan angka kesakitan dan kematian malaria lebih dari 50\% pada tahun 2010 dan lebih dari 75\% pada tahun 2015 dari angka tahun 2000 Pada tahun 2015, jumlah negara yang berhasil mengurangi angka kesakitan dan kematian malaria lebih dari $75 \%$ baru 57 negara dari 106 negara endemis malaria. ${ }^{2}$

Jumlah kasus malaria pada tahun 2015 diperkirakan 214 juta kasus dengan jumlah kematian sebanyak 438.000 kasus. Kasus malaria terbanyak terjadi di wilayah Afrika (88\%), diikuti wilayah Asia Tenggara (10\%), dan wilayah Mediterania Timur (2\%). Begitu juga dengan angka kematian terbanyak terjadi di wilayah Afrika (90\%), diikuti Wilayah Asia Tenggara (7\%), dan wilayah Mediterania Timur (2\%). Penyebab terbesar malaria di Asia Tenggara merupakan P. vivax $(74 \%){ }^{3}$

Di Indonesia point prevalence malaria menurut Riskesdas 2013 adalah 1,3\%, meningkat sekitar dua kali lipat dari tahun 2010, sedangkan untuk proporsi penduduk didapatkan penduduk pedesaan yang positif dua kali lipat $(1,7 \%)$ lebih banyak dibandingkan penduduk perkotaan $(0,8 \%)$. Berdasarkan kategori umur, prevalensi paling tinggi terjadi pada kelompok umur di atas 15 tahun. Salah satu komitmen pemerintah terhadap upaya pengendalian malaria telah diterbitkan keputusan Menteri Kesehatan pada tahun 2009 tentang eliminasi malaria di Indonesia yang dilakukan secara bertahap sampai dengan tahun $2030 .{ }^{4}$

Provinsi Aceh termasuk kedalam wilayah sasaran eliminasi malaria dimana persentase penderita malaria yang mendapatkan pengobatan efektif masih 33,3\% Pada tahun 2013 didapatkan kasus malaria berjumlah 2.412 kasus dengan kasus terbanyak ditemukan di Kabupaten Aceh Jaya yaitu sebanyak 1.364 kasus. Kasus malaria terbanyak di Aceh Jaya terjadi di Kecamatan Krueng Sabee yaitu 544 kasus. ${ }^{5}$

Direktorat Pemberantasan Penyakit Menular dan Kesehatan Lingkungan menggarisbawahi secara umum bahwa program pemberantasan malaria belum berhasil disebabkan karena malaria sangat dipengaruhi oleh faktor-faktor lingkungan (geografis, biogeografis, dan klimatologis), selain dari faktor-faktor epidemiologis, yaitu parasit malaria (Plasmodium), pejamu (manusia), dan vektor malaria (nyamuk Anopheles). Perubahan signifikan dari salah satu atau beberapa faktor lingkungan seperti faktor-faktor meteorologis, perkembangan alur irigasi, perubahan hutan dan kegiatan penambangan seringkali dapat mempengaruhi habitat larva dan dinamika transmisi malaria. ${ }^{6}$ Oleh karena itu, penelitian ini bertujuan untuk menganalisa faktor risiko lingkungan yang berhubungan dengan riwayat malaria pada siswa SMA 1 Krueng Sabee, Aceh Jaya. 


\section{Metode}

Penelitian ini merupakan penelitian observasional dengan rancangan potong lintang (cross sectional study), yaitu suatu rancangan penelitian yang mempelajari dinamika korelasi antara variabel independen dengan variabel dependen dengan melakukan pengukuran sesaat. Penelitian ini dilakukan pada SMA Negeri 1 Kueng Sabee. Populasi penelitian ini adalah seluruh siswa SMA 1 Krueng Sabee, Aceh Jaya. Metode pengambilan sampel adalah metode total sampling. Jumlah sampel dalam penelitian ini berjumlah 94 responden. Metode analisis data yang digunakan dalam penelitian ini yaitu sebagai berikut:

1. Analisis Univariat

Analisis univariat digunakan untuk mengetahui gambaran karakteristik responden berdasarkan faktor risiko lingkungan.

2. Analisis Bivariat

Analisis bivariat digunakan untuk mengetahui hubungan faktor risiko lingkungan dengan riwayat malaria menggunakan Uji Chi Square.

3. Analisis Multivariat

Analisis multivariat dilakukan untuk mengetahui variabel independen yang paling berpengaruh terhadap riwayat malaria pada siswa SMA Negeri 1 Krueng Sabee. Hasil analisis bivariat variabel independen yang mempunyai hubungan dengan riwayat malaria dilanjutkan analisis multivariat menggunakan analisis regresi logistik.

\section{Hasil Penelitian}

Analisis Univariat

\section{Karakteristik Faktor Risiko Lingkungan}

Karakteristik faktor risiko lingkungan ditunjukkan seperti pada tabel 1 berikut ini:

Tabel 1. Karakteristik Faktor Risiko Lingkungan

\begin{tabular}{lcc}
\hline \multicolumn{1}{c}{ Karakteristik Faktor Risiko Lingkungan } & N & $\%$ \\
\hline Keberadaan ventilasi rumah & 72 & 76,6 \\
Ada & 22 & 23,4 \\
Tidak ada & & \\
Keberadaan kawat kasa pada ventilasi & 17 & 18,1 \\
Ada & 77 & 81,9 \\
Tidak ada & & \\
Dinding rumah & 57 & 60,6 \\
Semi permanen & 37 & 39,4 \\
Permanen & & \\
Keberadaa langit-langit (plafon) & 40 & 42,6 \\
Ada & 54 & 57,4 \\
Tidak ada & & \\
Kondisi lantai rumah & 10 & 10,6 \\
Semi permanen & 84 & 89,4 \\
\hline Permanen &
\end{tabular}


Keberadaan genangan air

Ada

$79 \quad 84,0$

Tidak ada

$15 \quad 16,0$

Keberadaan semak-semak

Ada

$82 \quad 87,2$

Tidak ada

12

Keberadaan tumbuhan air

Ada

Tidak ada

$70 \quad 74,5$

Keberadaan kandang ternak

Ada

$35 \quad 37,2$

Tidak ada

59

62,8

Keberadaan mata air

$\begin{array}{lll}\text { Ada } & 14 & 14,9\end{array}$

Tidak ada

$80 \quad 85,1$

Sumber : data diolah 2016

Data pada tabel 1 di atas menunjukkan bahwa lingkungan tempat tinggal siswa SMA Negeri 1 Krueng Sabee masih buruk. Berdasarkan bentuk fisik rumah, sebagian besar rumah para responden belum terpasang kawat kasa pada ventilasi rumah (81,9\%). Dinding rumah para responden sebagian besar masih terbuat dari kayu atau semi permanen $(60,6 \%)$. Rumah para responden juga masih banyak yang belum terpasang langit-langit atau plafon (57,4\%). Kondisi lingkungan di sekitar rumah responden masih banyak terdapat genangan air berupa parit, bekas galian ataupun limbah air rumah tangga (84,0\%), dan masih banyak ditumbuhi semak-semak $(87,2 \%)$.

Berdasarkan karakteristik faktor risiko lingkungan pada tabel $1 \mathrm{di}$ atas, lingkungan tempat tinggal para siswa SMA Negeri 1 Krueng Sabee Aceh Jaya secara keseluruhan masih buruk (66,0\%) seperti ditunjukkan pada gambar 1 di bawah ini:

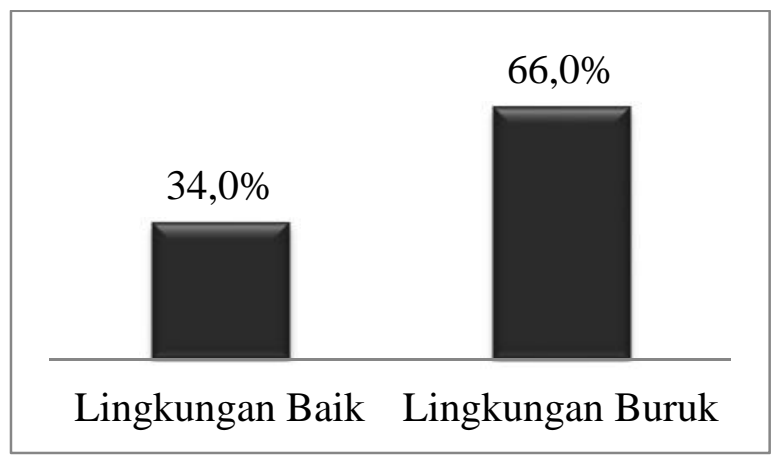

Gambar 1. Lingkungan Siswa SMA Negeri 1 Krueng Sabee

\section{Analisis Bivariat}

\section{Hubungan Faktor Risiko Lingkungan Dengan Riwayat Malaria}

Hasil analisis bivariat hubungan faktor risiko lingkungan dengan riwayat malaria pada siswa SMA Negeri 1 Krueng Sabee disajikan pada tabel 2 berikut ini: 
Tabel 2. Hubungan Faktor Risiko Lingkungan dengan Riwayat Malaria

\begin{tabular}{|c|c|c|c|}
\hline \multirow{2}{*}{ Faktor Risiko Lingkungan } & \multicolumn{2}{|c|}{ Riwayat Malaria } & \multirow{2}{*}{ Nilai P } \\
\hline & Pernah & Tidak Pernah & \\
\hline \multicolumn{4}{|l|}{ Keberadaan ventilasi rumah } \\
\hline Ada & 5 & 67 & \multirow[t]{2}{*}{0,204} \\
\hline Tidak ada & 0 & 22 & \\
\hline \multicolumn{4}{|c|}{ Keberadaan kawat kasa pada ventilasi } \\
\hline Ada & 3 & 14 & \multirow[t]{2}{*}{0,012} \\
\hline Tidak ada & 2 & 75 & \\
\hline \multicolumn{4}{|l|}{ Dinding rumah } \\
\hline Semi permanen & 5 & 57 & \multirow[t]{2}{*}{0,004} \\
\hline Permanen & 0 & 32 & \\
\hline \multicolumn{4}{|l|}{ Keberadaa langit-langit (plafon) } \\
\hline Ada & 0 & 40 & \multirow[t]{2}{*}{0,048} \\
\hline Tidak ada & 5 & 49 & \\
\hline \multicolumn{4}{|l|}{ Kondisi lantai rumah } \\
\hline Semi permanen & 1 & 9 & \multirow[t]{2}{*}{0,485} \\
\hline Permanen & 4 & 80 & \\
\hline \multicolumn{4}{|l|}{ Keberadaan genangan air } \\
\hline Ada & 4 & 75 & \multirow[t]{2}{*}{0,800} \\
\hline Tidak ada & 1 & 14 & \\
\hline \multicolumn{4}{|l|}{ Keberadaan semak-semak } \\
\hline Ada & 2 & 80 & \multirow[t]{2}{*}{0,001} \\
\hline Tidak ada & 3 & 9 & \\
\hline \multicolumn{4}{|l|}{ Keberadaan tumbuhan air } \\
\hline Ada & 2 & 22 & \multirow[t]{2}{*}{0,446} \\
\hline Tidak ada & 3 & 67 & \\
\hline \multicolumn{4}{|l|}{ Keberadaan kandang ternak } \\
\hline Ada & 2 & 33 & \multirow[t]{2}{*}{0,895} \\
\hline Tidak ada & 3 & 56 & \\
\hline \multicolumn{4}{|l|}{ Keberadaan mata air } \\
\hline Ada & 0 & 14 & \multirow[t]{2}{*}{0,336} \\
\hline Tidak ada & 5 & 75 & \\
\hline
\end{tabular}

Sumber: data diolah 2016

Hasil analisis bivariat faktor risiko lingkungan dengan riwayat malaria pada tabel 2 di atas menunjukkan bahwa, faktor risiko lingkungan yang berhubungan dengan riwayat malaria pada siswa SMA Negeri 1 Krueng Sabee (nilai $p \leq 0,05$ ) antara lain faktor risiko keberadaan kawat kasa pada ventilasi (nilai $\mathrm{p}=0,012$ ), faktor risiko kondisi dinding rumah (nilai $\mathrm{p}=0,004$ ), faktor risiko keberadaan langit-langit atau plafon (nilai $\mathrm{p}=0,048$ ), dan faktor risiko keberadaan semak-semak di sekitar rumah (nilai $\mathrm{p}=0,001$ ). Sedangkan faktor risiko lingkungan lainnya tidak mempunyai 
hubungan dengan riwayat malaria karena nilai $\mathrm{p}>0,05$.

\section{Analisis Multivariat}

Hasil analisis multivariat hubungan faktor risiko lingkungan dengan riwayat malaria pada siswa SMA Negeri 1 Krueng Sabee disajikan pada tabel 3 berikut ini:

Tabel 3. Hasil Analisis Multivariat

\begin{tabular}{|c|c|c|c|c|}
\hline \multirow{2}{*}{ Variabel } & \multirow{2}{*}{ P Value } & \multirow{2}{*}{ OR } & \multicolumn{2}{|c|}{ 95\% C.I.for EXP(B) } \\
\hline & & & Lower & Upper \\
\hline \multicolumn{5}{|l|}{ Faktor Risiko Lingkungan } \\
\hline Keberadaan kawat kasa & 0,039 & 13,536 & 1,026 & 38,350 \\
\hline Dinding rumah & 0,054 & 5,764 & 0,854 & 21,593 \\
\hline Keberadaan langit-langit & 0,042 & 9,621 & 0,076 & 26,367 \\
\hline Keberadaan semak-semak & 0,030 & 18,716 & 1,251 & 75,454 \\
\hline
\end{tabular}

Sumber: data diolah 2016

Tabel 3 di atas menunjukkan bahwa faktor risiko lingkungan yang paling berpengaruh terhadap riwayat malaria pada siswa SMA Negeri 1 Krueng Sabee yaitu faktor risiko keberadaan semak-semak di sekitar rumah dengan nilai p sebesar 0,030 dan nilai OR sebesar 18,716.

\section{Pembahasan}

Hasil analisis bivariat pada tabel 2 menunjukkan bahwa faktor risiko keberadaan kawat kasa pada ventilasi berhubungan dengan riwayat malaria pada siswa SMA Negeri 1 Krueng Sabee (nilai $p=$ 0,012). Sebagian besar rumah tempat tinggal para siswa tersebut tidak terpasang kawat kasa pada ventilasi rumah $(81,9 \%)$. Rumah dengan kondisi ventilasi tidak terpasang kasa nyamuk, akan memudahkan nyamuk untuk masuk ke dalam rumah untuk menggigit manusia dan untuk beristirahat. keberadaan ventilasi yang dilengkapi kasa berhubungan dengan kejadian malaria. ${ }^{7}$ Seseorang yang tinggal dalam rumah tidak dilengkapi dengan kawat kasa akan berisiko terkena malaria sebesar 3,41 kali\ dibandingkan yang tinggal di rumah dengan ventilasi memakai kawat kasa. Seseorang yang tinggal di rumah dengan kategori kondisi kasa pada ventilasi tidak rapat atau tidak ada sama sekali mempunyai risiko terkena malaria 6,5 kali lebih besar dari orang yang tinggal di rumah dengan kondisi kasa pada ventilasi terpasang dengan baik. ${ }^{8}$

Data pada tabel 2 juga menjelaskan bahwa faktor risiko kondisi dinding rumah mempunyai hubungan dengan riwayat malaria pada siswa SMA Negeri 1 Krueng Sabee (nilai $\mathrm{p}=0,004$ ). Dinding rumah para siswa SMA Negeri 1 Krueng Sabee sebagian besar masih berkontruksi kayu atau semi permanen $(60,6 \%)$. Dinding rumah yang berkontruksi kayu tidak rapat memungkinkan nyamuk untuk masuk melaui celah-celah kayu. Hasil penelitian yang dilakukan oleh Harmendo (2008) menunjukkan bahwa orang yang tinggal di rumah dengan kategori dinding tidak rapat mempunyai risiko terkena malaria lebih besar dari orang yang mempunyai rumah dengan kategori dinding rapat. Kondisi dinding rumah tidak rapat menyebabkan nyamuk Anopheles spp akan bebas masuk ke dalam rumah pada malam hari, sehingga penghuni rumah mempunyai risiko digigit nyamuk. Hal tersebut menyebabkan orang yang tinggal di rumah dengan ketegori dinding tidak rapat lebih berisiko tertular oleh malaria. ${ }^{8}$ Dinding rumah banyak 
berlubang mempunyai risiko terjadinya penularan malaria 3,9 kali dibandingkan dengan rumah yang tidak berlubang atau rapat. ${ }^{9}$ Sementara itu, Dinding rumah tidak rapat akan menyebabkan nyamuk masuk, beristirahat, dan menggigit manusia dalam rumah. Rumah dengan konstruksi yang baik dapat mengurangi kontak nyamuk dengan manusia sehingga memperkecil risiko penyakit yang ditularkan oleh nyamuk, sekalipun disekitar rumah tersebut terdapat perindukan nyamuk. ${ }^{7}$

Selanjutnya, hasil analisis bivariat pada tabel 2 menunjukkan bahwa faktor risiko keberadaan langit-langit berhubungan dengan riwayat malaria pada siswa SMA Negeri 1 Krueng Sabee (nilai $\mathrm{p}=0,048$ ). Rumah tinggal siswa SMA Negeri 1 Krueng Sabee sebagian besar belum terpasang langit-langit atau plafon (57,4\%). Kondisi rumah demikian membuat rumah banyak terdapat celah atau dapat mempermudah kemungkinan masuknya nyamuk ke dalam rumah, sehingga sangat besar kemungkinan penghuni rumah mempunyai kontak dengan nyamuk. Keberadaan langit-langit pada rumah merupakan faktor protektif terhadap terjadinya penyakit malaria ${ }^{10}$. Hal ini senada dengan penelitian yang dilakukan oleh Widaryani, dimana terdapat hubungan antara keberadaan langit-langit dengan kejadian malaria ${ }^{11}$. Seseorang yang tinggal di rumah yang tidak ada langit-langit mempunyai risiko 4,7 kali lebih besar terkena malaria dibandingkan dengan orang yang tinggal di rumah yang ada langitlangit. Langit-langit rumah merupakan faktor protektif terjadinya malaria karena dengan adanya langit-langit rumah dapat menghindari masuknya nyamuk secara leluasa ke dalam rumah. ${ }^{8}$

Hasil analisis bivariat pada tabel 2 juga menjelaskan bahwa faktor risiko keberadaan semak-semak berhubungan dengan riwayat malaria pada siswa SMA Negeri 1 Krueng sabee (nilai $p=0,001$ ), dan hasil analisis multivariat juga menunjukkan keberadaan semak- semak merupakan faktor risiko lingkungan yang paling berpengaruh terhadap riwayat malaria dengan nilai $\mathrm{p}$ sebesar 0,030 dan nilai OR sebesar 18,716. Di sekitar rumah tinggal para siswa tersebut banyak terdapat semaksemak $(87,2 \%)$. Semak-semak merupakan salah satu tempat perindukan nyamuk. Tempat perindukan nyamuk merupakan salah satu faktor yang berhubungan dengan kejadian penyakit malaria. Dimana orang yang rumahnya terdapat tempat perkembangbiakan nyamuk memiliki risiko terkena penyakit malaria lebih besar dibandingkan dengan orang yang rumahnya tidak terdapat tempat perkembangbiakan nyamuk. Hasil penelitian yang dilakukan Suwito (2005) di Wilayah Kerja Puskesmas Benteng Kabupaten Bangka Selatan menunjukkan bahwa adanya semak-semak merupakan faktor risiko kejadian malaria. Dimana, penghuni yang sekitar rumahnya terdapat semak-semak mempunyai risiko kejadian malaria 6,3 kali dibandingkan dengan penghuni yang lingkungan rumahnya tidak terdapat semak-semak. Semak-semak di sekitar rumah memegang peranan penting sebagai tempat peristirahatan bagi nyamuk pada siang hari. ${ }^{12}$

\section{Kesimpulan dan Saran}

\section{Kesimpulan}

1. Lingkungan tempat tinggal siswa SMA Negeri 1 Krueng Sabee masih buruk.

2. Faktor risiko lingkungan yang mempunyai hubungan dengan riwayat malaria adalah keberadaan kawat kasa, kondisi dinding rumah, keberadaan langit-langit (plafon), dan keberadaan semak-semak.

3. Keberadaan semak- semak merupakan faktor risiko yang paling berpengaruh terhadap riwayat malaria. 


\section{Saran}

1. Pihak SMA Negeri 1 Krueng Sabee hendaknya menjalin kerjasama dengan puskesmas untuk mengadakan penyuluhan kepada para siswa tentang pentingnya menjaga lingkungan guna mencegah terjadinya malaria.

2. Para siswa SMA Negeri 1 Krueng Sabee hendaknya menjaga kondisi lingkungan yang baik seperti memasang kawat kasa pada ventilasi rumah, membersihkan genangan air, dan semak-semak.

\section{Ucapan Terima Kasih}

Peneliti berterima kasih kepada Fakultas Kedokteran Universitas Malikussaleh yang telah memberi kesempatan untuk melakukan penelitian ini, dan juga kepada para responden yang telah bersedia ikut serta dalam penelitian ini.

\section{Daftar Pustaka}

1. Soedarto. 2011. Penyakit Menular di Indonesia. Jakarta: Sagung Seto.

2. Kemenkes RI. 2010. Riset Kesehatan Dasar 2010. Jakarta: Kementerian Kesehatan Republik Indonesia.

3. World Health Organization. 2015. World Malaria Report 2015. Genewa, Switzerland.

4. Kemenkes RI. 2013. Pokok-pokok Hasil RISKESDAS Indonesia Tahun 2013. Jakarta: Badan Penelitian dan Pengembangan Kesehatan Kementerian Kesehatan Republik Indonesia.

5. Dinkes Aceh. 2013. Profil Kesehatan Aceh Tahun 2013. Banda Aceh: Dinas Kesehatan Provinsi Aceh.

6. Depkes RI. 2008. Pedoman Pelaksanaan Kasus Malaria di Indonesia. Jakarta: Direktorat Jenderal PP\&PL Departemen Kesehatan Republik Indonesia.
7. Saputro KP dan Siwiendrayanti A. 2015. Hubungan Lingkungan Sekitar Rumah dan Praktik Pencegahan dengan Kejadian Malaria di Desa Kendaga Kecamatan Banjarmangu Kabupaten Banjarnegara Tahun 2013. Unnes Journal of Public Health; 4(2).

8. Harmendo. 2008. Faktor Risiko Kejadian Malaria di Wilayah kerja Puskesmas Kenanga Kecamatan Sungailat Kabupaten Bangka Propinsi Kepulauan Bangka Belitung. Tesis. Semarang: Universitas Diponegoro.

9. Hayati F dan Wahyuningsih NE. 2008. Hubungan Kondisi Fisik Rumah, lingkungan Sekitar Rumah dan Praktik Pencegahan dengan Kejadian Malaria di Wilayah Kerja Puskesmas Pangandaran Kabupaten Ciamis. Tesis. Semarang: Universitas Diponegoro.

10. Yawan SF, Sulistiyani, dan Barodji. 2006. Analisis Faktor Risiko Kejadian Malaria di Wilayah Kerja Puskesmas Bosnik Kecamatan Biak Timur Kabupaten Biak-Numfor Papua Tahun 2006. Jurnal Kesehatan Lingkungan Indonesia; 5(2):45-52.

11. Widaryani T. 2006. Alternatif Program pemberantasan Malaria di Daerah Endemis di Kabupaten Toli-Toli Propinsi Sulawesi Tengah. http://adln.lib.unair.ac.id/go.php?id=j iptunair-gdl-s2-2004-widaryanit1231\&PHPSESSID=93e1c24e594d6eb45 6af7af25091310f

12. Suwito. 2005. Studi Kondisi Lingkungan Rumah dan Perilaku Masyarakat Sebagai Faktor Risiko Kejadian Malaria di Wilayah Kerja Puskesmas Benteng Kabupaten Bangka Tengah Propinsi Kepulauan Bangka Belitung, Tesis. Semarang: Universitas Diponegoro. 